University of Nebraska - Lincoln

DigitalCommons@University of Nebraska - Lincoln

2010

\title{
A General Approach for Receptor and Antibody-Targeted Detection of Native Proteins Utilizing Split-Luciferase Reassembly
}

\author{
Cliff I. Stains \\ University of Nebraska-Lincoln, cstains2@unl.edu \\ Jennifer L. Furman \\ University of Arizona \\ Jason R. Porter \\ University of Arizona \\ Srivats Rajagopal \\ University of Arizona \\ Richard T. Wyatt \\ Vaccine Research Center, National Institutes of Health, Bethesda, Maryland \\ See next page for additional authors
}

Follow this and additional works at: https://digitalcommons.unl.edu/chemistrystains

Part of the Chemistry Commons

Stains, Cliff I.; Furman, Jennifer L.; Porter, Jason R.; Rajagopal, Srivats; Wyatt, Richard T.; and Ghosh, Indraneel, "A General Approach for Receptor and Antibody-Targeted Detection of Native Proteins Utilizing Split-Luciferase Reassembly" (2010). Cliff Stains Publications. 2.

https://digitalcommons.unl.edu/chemistrystains/2

This Article is brought to you for free and open access by the Published Research - Department of Chemistry at DigitalCommons@University of Nebraska - Lincoln. It has been accepted for inclusion in Cliff Stains Publications by an authorized administrator of DigitalCommons@University of Nebraska - Lincoln. 


\section{Authors}

Cliff I. Stains, Jennifer L. Furman, Jason R. Porter, Srivats Rajagopal, Richard T. Wyatt, and Indraneel Ghosh 


\title{
A General Approach for Receptor and Antibody-Targeted Detection of Native Proteins Utilizing Split-Luciferase Reassembly
}

\author{
Cliff I. Stains ${ }^{\dagger, \|}$, Jennifer L. Furman ${ }^{\dagger, \|}$, Jason R. Porter ${ }^{\dagger}$, Srivats Rajagopal ${ }^{\dagger}$, Yuxing Li $i^{\ddagger}$, \\ Richard T. Wyatt ${ }^{\ddagger}, \S$, and Indraneel Ghosh ${ }^{\dagger, *}$ \\ ${ }^{\dagger}$ Department of Chemistry and Biochemistry, University of Arizona, 1306 E. University Blvd., Tucson, Arizona 85721 and \\ ${ }^{\text {}}$ Vaccine Research Center, National Institutes of Health, Bethesda, Maryland 20892, \$Present address: Department of \\ Immunology, The Scripps Research Institute., "These authors contributed equally to this work.
}

K nowledge of aberrant protein expression patterns can be employed toward predicting outcomes to conventional therapy and aid in the development of individualized treatment (1). This is particularly evident in the treatment of breast cancer in which the expression of estrogen, progesterone, and human epidermal growth factor receptor 2 (HER2) is used to stratify patients and guide the administration of both chemical and biological therapeutic agents (2). Taking a broader view, the interactions of cell surface receptors with their ligands play an important role in almost all viral infection as well as the initiation of signaling cascades. For example, the interaction of the gp120 coat protein of HIV-1 with the CD4 receptor of T-lymphocytes leads to infection (3), while the interaction of the vascular endothelial growth factor (VEGF) with its receptor Flt-1 leads to angiogenesis, thereby potentiating tumor growth (4). Consequently, simple and rapid methods for the direct detection of cellular receptors are desirable.

Elegant strategies for labeling and detecting native proteins in biological settings have been described; however, many of these methods are encumbered by the inherent requirement for separation or chemical labeling (5). Current approaches often rely on chemical or biological derivatization and subsequent analysis by microscopy or fluorescence-activated cell sorting (FACS)

(6). Alternatively, the classic enzyme-linked immunosorbent assay (ELISA) $(7,8)$ can be used to detect almost any analyte but requires that either the antigen or antibody is captured on a solid support prior to detection, followed by vigorous washing and subsequent recognition by an enzyme-secondary-antibody conjugate. This
AB STRACT The direct detection of native proteins in heterogeneous solutions remains a challenging problem. Standard methodologies rely on a separation step to circumvent nonspecific signal generation. We hypothesized that a simple and general method for the detection of native proteins in solution could be achieved through ternary complexation, where the conditional signal generation afforded by split-protein reporters could be married to the specificity afforded by either native receptors or specific antibodies. Toward this goal, we describe a solution phase split-luciferase assay for native protein detection, where we fused fragmented halves of firefly luciferase to separate receptor fragments or single-chain antibodies, allowing for conditional luciferase complementation in the presence of several biologically significant protein targets. To demonstrate the utility of this strategy, we have developed and validated assay platforms for the vascular endothelial growth factor, the gp120 coat protein from HIV-1, and the human epidermal growth factor receptor 2 (HER2), a marker for breast cancer. The specificities of the recognition elements, CD4 and the 17b single-chain antibody, employed in the gp120 sensor allowed us to parse gp120s from different clades. Our rationally designed HER2 sensing platform was capable of discriminating between HER2 expression levels in several tumor cell lines. In addition, luminescence from reassembled luciferase was linear across a panel of cell lines with increasing HER2 expression. We envision that the proof of principle studies presented herein may allow for the potential detection of a broad range of biological analytes utilizing ternary split-protein systems.

\section{${ }^{*}$ Corresponding author,}

ghosh@email.arizona.edu.

Received for review May 22, 2010

and accepted July 23, 2010.

Published online July 23, 2010

10.1021/cb100143m

() 2010 American Chemical Society 


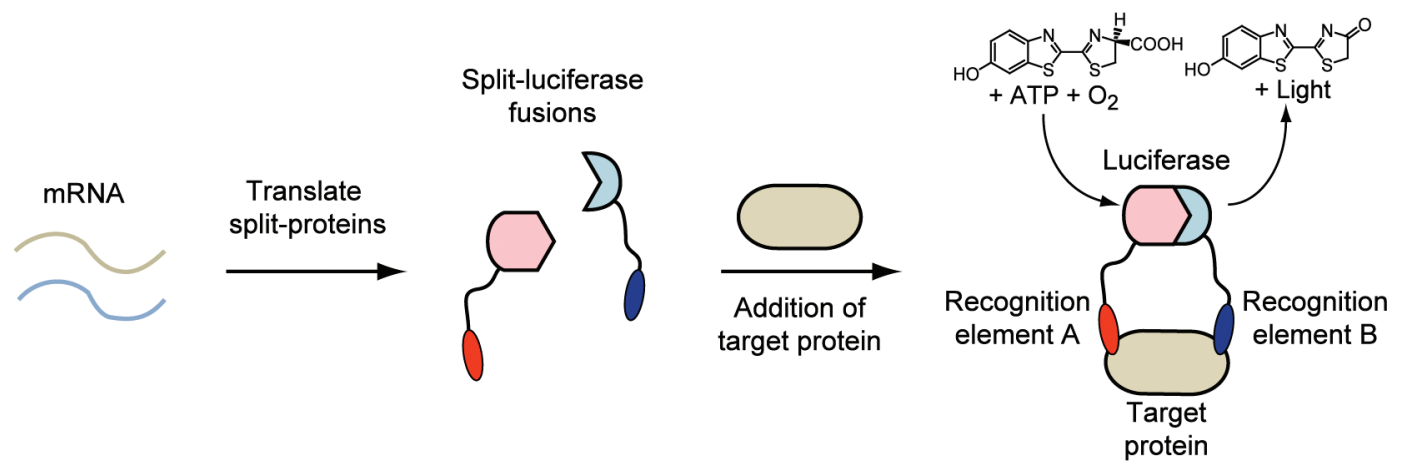

Figure 1. General schematic for ternary complexation mediated protein complementation is shown. mRNA encoding for split-luciferase fusions is used to initiate translation in a cell-free protein expression system. Specific recognition elements fused to the luciferase halves are used to reassemble a functional enzyme in the presence of a protein of interest leading to the generation of light. Translation, reassembly, and detection take place in the same solution.

limits the utility of the ELISA for the direct detection of native proteins in complex heterogeneous fluids, such as blood or lysates. We note that techniques such as time-resolved fluorescence that exploit the long fluorescence lifetime of lanthanides such as $\mathrm{Eu}^{3+}$ also provide sensitive methods for protein detection that avoid complications associated with biological autofluorescence $(9,10)$. Ideally one could envision a one-step solution phase sandwich approach in which the activity of an attached split-protein reporter would depend solely upon formation of a ternary complex (Figure 1). Such a general methodology would potentially allow for the direct detection of any protein in complex environments without the need for immobilization, direct chemical derivatization, or separation.

Central to the strategy proposed above is the use of split-protein reassembly or protein complementation, which relies on a specific bimolecular interaction to drive reassembly of a fragmented reporter protein (11, 12). Johnsson and Varshavsky were the first to demonstrate this approach using split-ubiquitin (13), which has subsequently been applied to a variety of monomeric reporter proteins including dihydrofolate reductase (DHFR) (14), $\beta$-lactamase (15), GFP (16-18), Renilla luciferase (19), Gaussia luciferase (20), firefly luciferase (21), Trp1p (22), TEV protease (23), and most recently, chorismate mutase (24). This enabling principle for the detection of bimolecular interactions has been used to delineate the yeast protein interactome (25) and could potentially lead to novel treatments for cancer (26). We have utilized this approach for the direct detection of DNA through ternary complexation
(27-29), which was also utilized for the site-specific methylation of DNA (30). We sought to make use of the ternary complexation principle to develop a conditional detection platform for native extracellular proteins in heterogeneous solutions utilizing receptor fragments and antibodies as specific recognition elements.

Toward this long-term goal, we recently described a general cell-free split-protein assay for directly measuring heterodimeric protein-protein interactions (31). We identified a fragmented luciferase (32), discovered by Luker et al. through the incremental truncation approach (33), as a very sensitive protein complementation platform adaptable to a cell-free system $(34,35)$. Herein we adapt the cell-free split-luciferase methodology to provide a simple and potentially general solution for the rapid and direct detection of clinically relevant proteins, including growth factors as well as viral- and cell-surface receptors.

\section{RESULTS AND DISCUSSION}

\section{A Cell-Free Split-Luciferase System for VEGF}

Detection. As a first test of ternary complexation, we set out to determine if a dimeric receptor fragment could be utilized to detect its extracellular ligand. We chose to target dimeric VEGF, implicated in tumor angiogenesis, which binds its extracellular receptor Flt-1 in a 1:2 stoichiometry with a reported $K_{\mathrm{d}}$ of $1.4 \mathrm{nM}$ (36). We next attached the $\mathrm{N}$ - and $\mathrm{C}$-terminal halves of luciferase (residues $2-416$ and $398-550$, respectively) to separate Flt-1 domain 2 fragments (Figure 2, panel A) with the expectation that a statistical distribution of Flt-1-luciferase halves bound to the VEGF dimer would still permit 
A

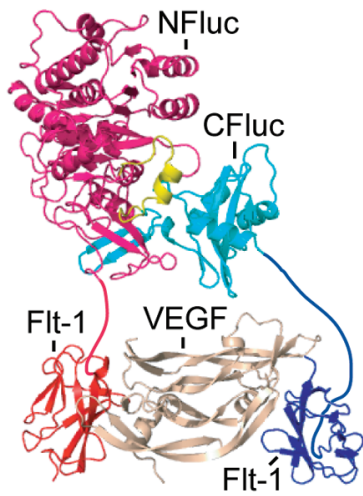

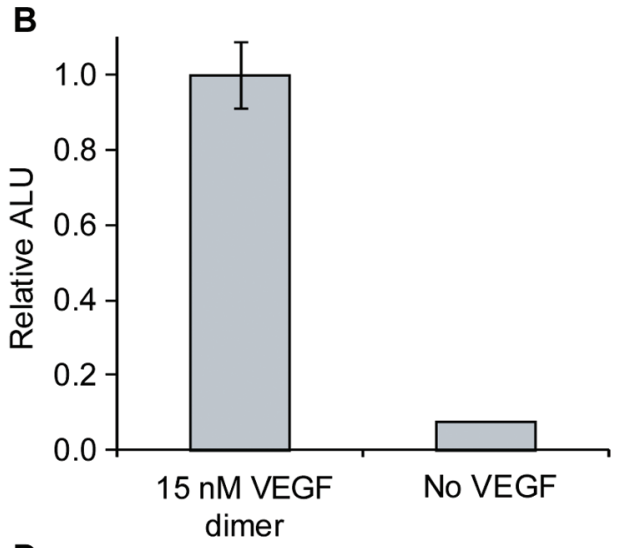

D

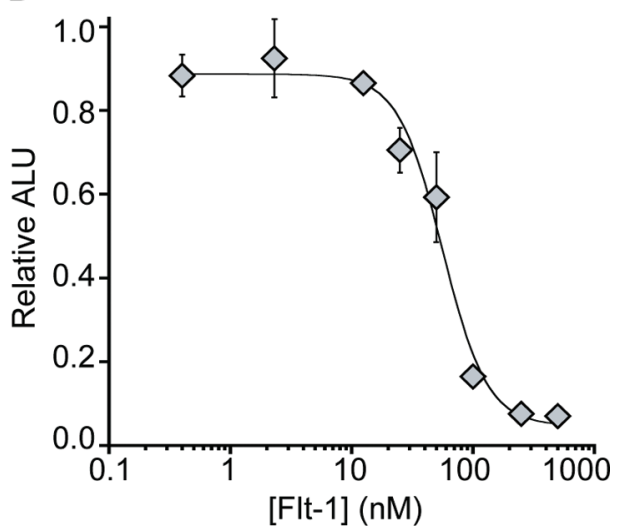

B

[Flt-1] (nM)
C

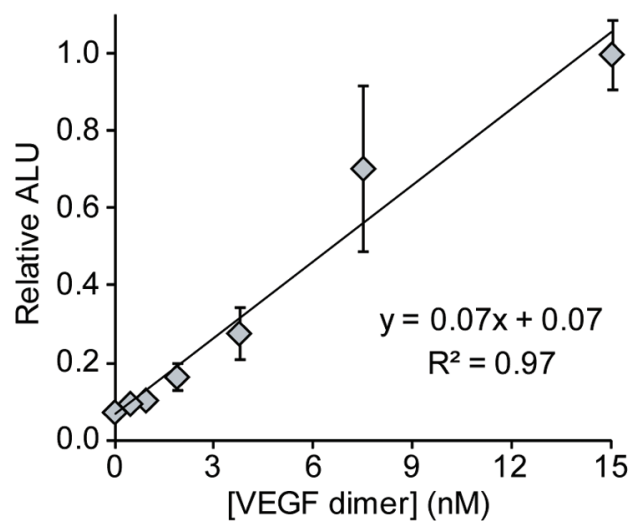

Figure 2. Ternary complexation mediated direct detection system for the vascular endothelial growth factor (VEGF). A) A schematic of the VEGF assay is shown, where domain 2 of Flt-1 (red and blue) is attached to both the $\mathrm{N}$ - and $\mathrm{C}$-terminal halves of luciferase to directly detect the VEGF homodimer. B) Luminescence from reassembled luciferase in the presence and absence of VEGF, total assay time of $2.5 \mathrm{~h}$ starting from mRNA. A >13-fold increase in luminescence is observed in the presence of $15 \mathrm{nM}$ VEGF dimer. C) A titration of VEGF dimer was performed, resulting in a linear relationship to luminescence output. D) A titration of free Flt-1 was used to compete with luciferase reassembly, resulting in an $\mathrm{IC}_{50}$ of $56 \pm 8 \mathrm{nM}$. ALU, arbitrary luminescence units.

$\sim 50 \%$ split-luciferase complementation. Expression of the split luciferase-Flt-1 fusion proteins in rabbit reticulocyte lysate led to an increase in luminescence of $>13$ fold only in the presence of 15 nM VEGF dimer, clearly demonstrating the ability to use receptor fragments to detect their ligands in this system (Figure 2, panel B). This detection system could potentially provide a means for high-throughput screening of molecules capable of disrupting the interaction of VEGF with its receptor (4). To further confirm the interaction between VEGF and Flt-1, we recombinantly expressed soluble fragments of these proteins (Supplementary Figure S1) and demonstrated a 1:2 binding interaction between the VEGF dimer and Flt-1 by gel filtration (Supplementary Figures S2 and S3). We additionally determined the limit of VEGF dimer detection by performing a titration, demonstrating detection of 500 pM (690 ng) VEGF dimer above two standard deviations from the average background signal (Figure 2, panel C). To demonstrate reversibility of VEGF/Flt-1 dependent split-luciferase reassembly, we sought to compete for VEGF binding by adding free Flt-1 in trans (Figure 2, panel D). Titration of a solution containing $15 \mathrm{nM}$ VEGF dimer with free Flt-1 resulted in an $I_{50}$ of $56 \pm 8 \mathrm{nM}$. We note that the concentration of the sensor components in the system are not known, and thus this approach provides information on relative 
A

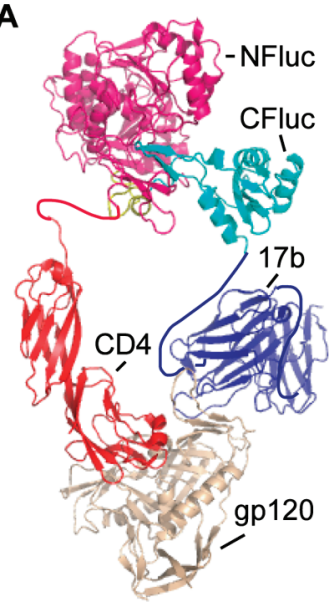

B

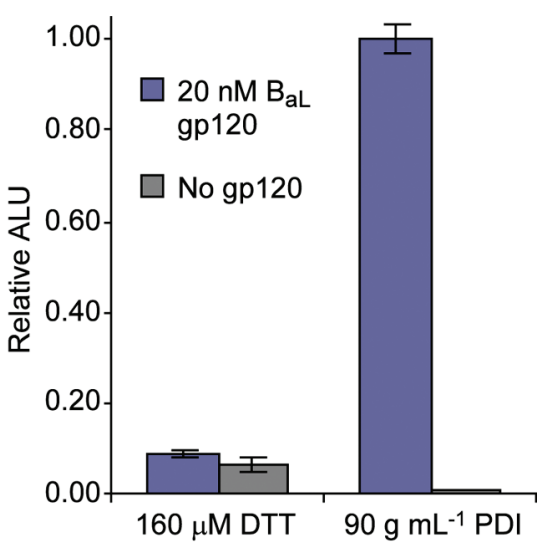

Figure 3. Antibody enabled split-luciferase assay for direct detection of gp120. A) A schematic of the solution phase detection system for gp120 is shown. B) The specificity of the solution phase gp120 detection system is shown, emphasizing the luminescence signal generated from the assay when either DTT or PDI is included during translation. ALU, arbitrary luminescence units. DTT, dithiothreitol. PDI, protein disulfide isomerase.

binding constants rather than absolute equilibrium constants as is the case with fluorescence polarization or surface plasmon resonance. Finally, we tested whether the split-luciferase assay platform is compatible with the use of cell lysis reagents and protease inhibitors that may be present in certain samples and found that the luminescence signal was not significantly diminished (Supplementary Figure S4). Importantly, these initial experiments with VEGF and Flt-1 established feasibility for our direct ternary complexation strategy, prompting us to further investigate the use of more general recognition scaffolds such as antibodies.

Rapid Characterization of HIV-1 Clades. As our first test of antibody mediated detection, we sought to provide a rapid and sensitive method for detecting HIV-1 based on antibody specificities. Accordingly we investigated strategies for incorporating antibodies into splitprotein reassembly assays. In efforts to generate antibodies from randomized libraries, the Plückthun laboratory demonstrated that split-DHFR could be reassembled in bacterial cells by attaching a protein of interest and the corresponding single-chain antibody (scFv), a covalent fusion of the variable heavy and light chains (37-39), to individual DHFR halves (40). Interaction dependent reassembly of the functional DHFR enzyme led to cell survival. Despite its appeal, the intracellular expression of functional scFvs remains challenging (41,

42). Alternatively, conditions for efficient scFv expression and refolding in cell-free translation systems supplemented with protein disulfide isomerase (PDI) have been described (43). With this in mind, we set out to develop an antibody mediated split-luciferase assay for the potential detection of HIV-1.

The crystal structure of the complex between CD4, gp120, and the Fab portion of a neutralizing antibody $17 b(3)$, which has a high affinity for Clade $B B_{a L}$ gp120 (44), served as a model system for the development of our gp120 sandwich assay (Figure 3, panel A). We fused domain 1 and 2 (D1D2, residues 1-182) of CD4, which has been shown to bind to gp120 with a $K_{d}$ of $\sim 3 \mathrm{nM}$ (45), to the N-terminal half of luciferase. As our second recognition element, we fused the C-terminal half of luciferase to the $17 \mathrm{~b}$ scFv, which binds a CD4-induced epitope of gp120 (3, 44) (Figure 3, panel A). In accordance with previous literature results, initial experiments showed a negligible increase in luminescence for translations conducted in the presence of $20 \mathrm{nM} \mathrm{BaL}$ gp120 (Supplementary Figure S5), presumably due to improper folding of the $17 \mathrm{~b}$ scFv (43). However, the elimination of DTT and addition of PDI allowed for luminescence and the first functional demonstration of antibody mediated targeting in the split-luciferase system (Figure 3, panel B). Moreover, luminescence signal was detectable without the need for separation, washing, or subsequent derivatization.

Having established conditions for favorable protein folding, we sought to verify the specificity of our gp120 assay. Accordingly, we first investigated luciferase reassembly in the presence of different $B_{a L}$ gp120s containing single amino acid mutations, D368R and 1420R, which are known to reduce either CD4 (46) or 17b (47) binding, respectively. Indeed these mutant gp120s considerably reduce luminescence relative to the wildtype, confirming that both functional CD4 and 17b binding are required for luciferase reassembly (Figure 4, panel A). We also interrogated split-luciferase activity as a function of gp120 concentration (Supplementary Figure S6), demonstrating that our assay system is capable of reporting on the presence of at least $12 \mathrm{ng} \mathrm{mL}^{-1}$ of $B_{a L}$ gp120, which is comparable to commercially available gp120 ELISAs and is likely a function of antibody/D1D2 affinities. This titration experiment also indicated that $\sim 5 \mathrm{nM}$ of active complex (folding capable split-halves) is translated utilizing our current cell-free conditions. 
To use our sandwich assay for the potential characterization of HIV-1 clades, we investigated gp120s from isolates CN54 and 96ZM651, both of which are clade C viruses. Maximal luciferase signal was observed only in the presence of $B_{a L}$ gp120 (clade B), while a slight increase in luminescence was observed for CN54 gp120, and no detectable signal was generated for 96ZM651 gp120 (Figure 4, panel B). This highlights the potential feasibility of this complexation approach for providing a method for distinguishing HIV-1 clades and subtypes using known antibody specificities without the need for DNA sequencing. In the long term, to accurately profile HIV-1, a panel of known gp120 antibodies with predetermined specificities is necessary that can be attached to the two halves of luciferase $(44,48)$. An unknown sample would be interrogated against the splitluciferase panel to potentially determine the specific HIV-1 clade.

\section{Probing HER2 Expression in Human Breast Cancer} Cells. Having identified suitable expression conditions for using scFvs in our split-luciferase system, we turned to establishing whether this assay can be utilized for the determination of the relative levels of cell surface proteins present in human cells. This is particularly relevant to breast cancer treatment where the expression of estrogen receptors, progesterone receptors, and HER2 in tumors is used to stratify patients and guide treatment strategies (2). Therefore we chose to develop a general method for detecting extracellular receptors using scFvs as protein recognition elements. Specifically we chose the extracellular domain (ECD, residues 1-631) of HER2, which is overexpressed in $\sim 30 \%$ of human breast cancers and is directly correlated with poor clinical outcomes. Genentech has described two antibodies, Herceptin and Omnitarg, which bind distinct epitopes of the HER2 ECD. Overlaying the crystal structures of these bound antibodies indicates that they are likely capable of binding HER2 simultaneously $(49,50)$. Moreover the reported binding constants for an scFv version of Herceptin and the Fab portion of Omnitarg for the HER2 ECD are $150 \mathrm{pM}$ (51) and $8.5 \mathrm{nM}$ (52), respectively, which is well within our assay's detection limits. Thus we constructed mRNAs in which the scFv of Omnitarg was fused to the $\mathrm{N}$-terminal portion of luciferase and the C-terminal portion of luciferase was fused to the scFv of Herceptin (Figure 5, panel A). As an initial test of the HER2 sandwich assay, the HER2 ECD was expressed, purified, and added at varying concentrations
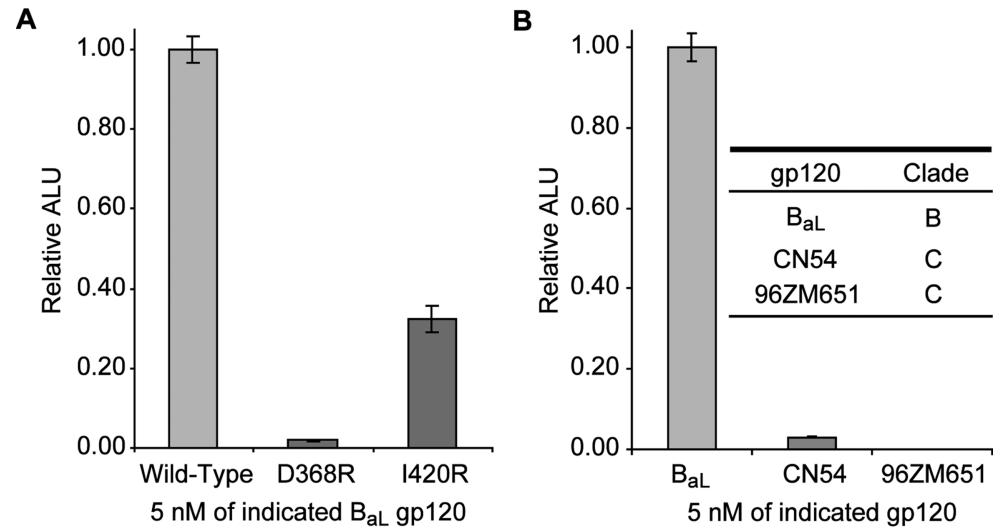

Figure 4. Antibody enabled split-luciferase assay for direct detection of gp120 and verification of clades. A) The specificity of the solution phase gp120 detection system is shown. Assays were performed on the indicated wild-type or mutant gp120s; D368R and 1420R mutations are known to decrease CD4 or 17b binding respectively $(46,47)$. B) The specificity of the antibody mediated gp120 detection system, as determined by luciferase reassembly, across a panel of gp120s from the indicated clades is shown. The observed luminescence highlights the potential ability to rapidly categorize HIV-1 clades using scFv-based split-luciferase complementation. ALU, arbitrary luminescence units.

to the two split-luciferase scFv fusions after translation in rabbit reticulocyte lysate. Within $30 \mathrm{~min}$ a concentration-dependent increase in luminescence in the presence of the HER2 ECD was observed (Figure 5, panel B), indicating that this new antibody enabled sandwich assay was indeed capable of reporting on
A

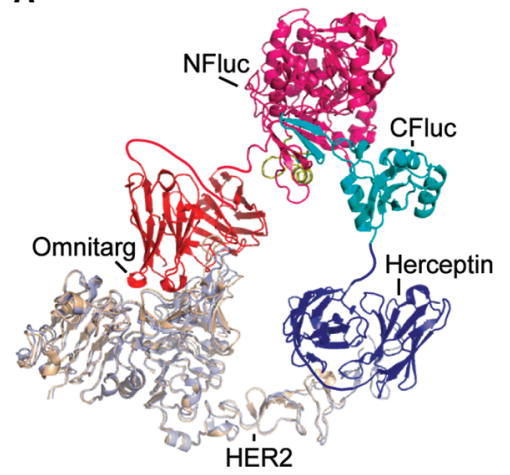

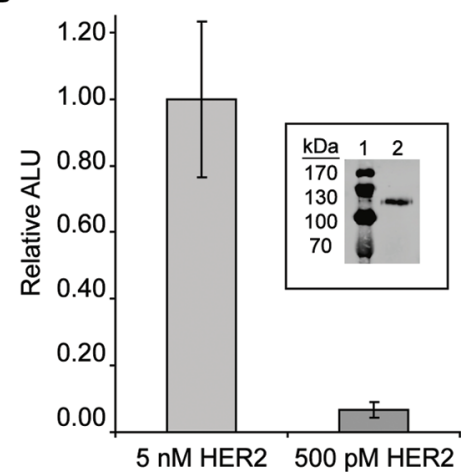

Figure 5. Dual antibody mediated split-luciferase sandwich assay for the direct detection of purified human epidermal growth factor receptor 2 (HER2). A) An overlay of HER2 (tan and light blue) with the bound luciferase fusion proteins is shown. B) A HER2 sandwich assay was performed on purified HER2 expressed from Lec1 cells. The inset shows a Western blot analysis of the purified HER2 protein, lane 1 molecular weight standards and lane 2 purified HER2 protein. ALU, arbitrary luminescence units. 
A

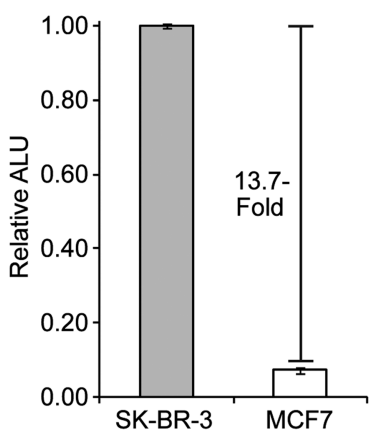

B

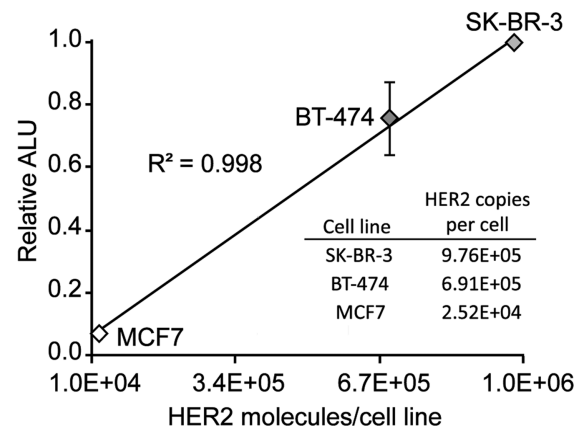

Figure 6. Dual antibody mediated split-luciferase sandwich assay for the direct detection of human epidermal growth factor receptor 2 (HER2) in human breast cancer cells. A) A HER2 sandwich assay was performed on human breast cancer cells. SKBR-3 or MCF7 cells were added after translation and luminescence was monitored after $40 \mathrm{~min}\left(2.5 \times 10^{4}\right.$ cells during luminescence assay). B) The luminescence signal obtained from the HER2 sandwich assay correlates with literature values for HER2 expression in the corresponding cell lines (53). ALU, arbitrary luminescence units.

the presence of HER2 at subnanomolar levels. Preliminary experiments indicate that these cell-free translations can be stored at least 7 days at $-80^{\circ} \mathrm{C}$ prior to the addition of HER2 (Supplementary Figure S7), potentially allowing for the long-term storage of reagents and the detection of clinically relevant analytes at the point of care.

Finally we sought to determine if our assay could directly detect differential levels of expression of HER2 in human breast cancer cells. We chose the SK-BR-3, BT474, and MCF7 cell lines, which have been shown to produce approximately $1 \times 10^{6}, 7 \times 10^{5}$, and $2.5 \times 10^{4}$ copies of HER2 per cell, respectively (53). Cells were added directly to completed translation reactions and incubated at RT for $40 \mathrm{~min}$. In the presence of SK-BR-3 cells $\left(2.5 \times 10^{4}\right.$ cells, theoretically $\left.\sim 400 \mathrm{pM} \mathrm{HER} 2\right)$ a 13.7-fold increase in luminescence was observed with respect to the MCF7 cells $\left(2.5 \times 10^{4}\right.$ cells, theoretically $\sim 11 \mathrm{pM}$ HER2), indicating that our sandwich assay is capable of directly reporting on the differential expression levels of HER2 in human breast cancer cell lines (Figure 6, panel A). Finally, in the presence of the BT474 cell line an intermediate signal was observed, which was proportional to the theoretical amount of HER2 in the assay, $\sim 280 \mathrm{pM}$. These combined trends in luminescence signal directly correlated to the known expression levels of HER2 in these cell lines (Figure 6, panel B) (53). These results indicate that this rapid assay is capable of directly determining the relative ex-

pression levels of HER2 in human cells without the need for separation or FACS analysis. Additional experiments indicate that as few as 2,600 SK-BR-3 cells can be detected using this assay format (Supplementary Figure S8). These results highlight the potential utility of this assay platform for the rapid stratification of breast cancer patients based on receptor expression.

\section{CONCLUSIONS}

We have demonstrated the feasibility of ternary protein detection utilizing split-protein reassembly. Using this approach, we initially attached the receptor fragments of Flt- 1 to the fragmented luciferase halves to detect VEGF, which could potentially be applied to identify molecules with antiangiogenic properties. Our current sensitivity for this assay is $690 \mathrm{ng}$ of VEGF dimer, which is on the same scale as physiological concentrations of VEGF in the sera or effusions from cancer patients reported to be as high as $50 \mathrm{ng} \mathrm{mL}^{-1}$ (54). In order to develop a more general recognition strategy, we have successfully employed single-chain antibodies as specific recognition elements. This approach was validated utilizing a single-chain antibody and a cellular receptor fragment as targeting domains, which were utilized to demonstrate the long-term potential for the characterization of HIV-1 clades by means of specific antibodygp120 mediated recognition panels. Finally, we extended this ternary approach for the determination of the relative levels of HER2 in human breast cancer cells using an entirely antibody-based recognition system. This strategy requires the identification of dual recognition elements capable of simultaneously binding to the target of interest, which may be generally accessible through elegant methods for the evolution of antibody fragments (55). We envision that this simple and potentially general methodology will provide an approach for the rapid detection of a broad range of native proteins in complex heterogeneous systems, including blood and tissues. Furthermore, this assay might be useful for monitoring protein complex formation to follow aspects of stem cell differentiation or cancer cell progression, utilizing the unique cell-surface markers of stem cells that can provide a handle for following mechanisms of pluripotency maintenance and lineage commitment (56). The use of the firefly luciferase reporter with a broad luminescence profile with a maximum at $560 \mathrm{~nm}$ (range $\sim 500-650$ ) is particularly attractive in a biological context, considering that emission wavelengths greater 
than $600 \mathrm{~nm}$ are more easily transmitted through mammalian tissues $(57,58)$. However, a further red-shifted luciferase variant, such as railroad worm luciferase with a maximum emission at $630 \mathrm{~nm}$, may prove even more appropriate for biological imaging (59). More generally, this ternary capture approach demonstrates the ability to generate conditionally activated split-proteins dependent upon native protein abundance, which may be potentially redesigned for therapeutic or drug delivery applications.

\section{METHODS}

General Materials. Flexi-Rabbit Reticulocyte Lysate, RNasin, Steady-Glo Luciferase Assay System, and the T7 Ribomax Transcription Kit were purchased from Promega. G50 ProbeQuant columns were obtained from GE Healthcare. XL-1 Blue E. coli cells were purchased from Stratagene. Ni-NTA agarose resin was purchased from Qiagen. $\mathrm{B}_{\mathrm{aL}}$, CN54, and 96ZM651 gp120s were obtained from the NIH AIDS Reference and Reagent Program, catalog numbers 4961, 7749, and 10080 respectively. Wildtype $B_{\text {aL }}$ gp120 and the $B_{\text {aL }}$ gp120 D368R and I420R mutants used in Figure 4, panel $A$ were a generous gift of R. Wyatt. PDI, the Ala-Gln dipeptide, and Trypan Blue were purchased from Sigma. SK-BR-3 and BT-474 cells were obtained from ATCC (HTB-30 and HTB-20). MCF7 cells were a generous gift of the B. Olenyuk laboratory. Cell culture media and reagents were purchased from Hyclone. Plasmids encoding the $V_{H}$ and $V_{L}$ regions of both Herceptin (60) and Omnitarg (52) separated by a $(\mathrm{GGGGS})_{3}$ linker were purchased from Bio Basic.

VEGF Expression and Refolding. A pQE30-VEGF expression plasmid was transformed into XL-1 Blue $E$. coli by electroporation according to the manufacturer's instructions. An overnight culture of these cells was used to inoculate a $1 \mathrm{~L}$ culture of $2 \mathrm{XYT}$ media supplemented with $100 \mu \mathrm{g} \mathrm{mL} \mathrm{L}^{-1}$ ampicillin at an $\mathrm{OD}_{600}$ of 0.05 . Protein expression was induced at an $\mathrm{OD}_{600}$ of 0.8 with $1 \mathrm{mM}$ IPTG. Protein expression was allowed to proceed overnight at $37^{\circ} \mathrm{C}$. Cells were pelleted by centrifugation and resuspended in lysis buffer (Tris- $\mathrm{HCl}$ at $\mathrm{pH}=8$ containing $8 \mathrm{M}$ Urea). Resuspended cells were lysed by sonication. The lysate was cleared by centrifugation at $18,000 \mathrm{rcf}$ for $30 \mathrm{~min}$. His-tagged VEGF was purified under denaturing conditions using Ni-NTA resin using the manufacturer's instructions. Imidazole wash fractions were collected, pooled, and stored at $-20^{\circ} \mathrm{C}$ until required. Collected fractions were thawed on ice, concentrated, and FPLC purified using a preparative Hi-Load 16/60 Superdex 75 column (Pharmacia Biotech) equilibrated with denaturing buffer (Tris- $\mathrm{HCl}$ at $\mathrm{pH}=8$ containing $6 \mathrm{M}$ Urea). Full length monomeric VEGF was isolated, pooled, and stored at $-20^{\circ} \mathrm{C}$ until required for refolding.

The pooled fractions containing full-length monomeric VEGF were diluted to $50 \mu \mathrm{g} \mathrm{mL}^{-1}$ with buffer containing $6 \mathrm{M}$ urea, $0.1 \mathrm{M} \mathrm{Na}_{2} \mathrm{HPO}_{4}, 10 \mathrm{mM}$ Tris- $\mathrm{HCl}$ at pH $=8.5,1 \mathrm{mM}$ EDTA, and $20 \mathrm{mM}$ DTT. This solution was incubated for $3 \mathrm{~h}$ at RT to facilitate reduction. Reduced monomeric VEGF was then dialyzed against $100 \mathrm{mM}$ Tris- $\mathrm{HCl}$ at $\mathrm{pH}=8.5,5 \mathrm{mM}$ cysteine, $1 \mathrm{mM}$ cystine, $0.5 \mathrm{M}$ Urea, and $2 \mathrm{mM}$ EDTA overnight at RT.

To separate dimeric VEGF from monomeric and multimeric species the refolded VEGF was concentrated and purified by FPLC using a Superdex 75 column equilibrated with PBS. Fractions containing refolded dimeric VEGF were collected, pooled, concentrated, and reapplied to the Superdex 75 column. Refolded VEGF was characterized by SDS-PAGE under reducing and nonreducing conditions to visualize the monomeric versus dimeric form. Concentrations were obtained by UV absorbance.

Flt-1 Expression and Refolding. A pRSFDuet-Flt-1 expression plasmid was transformed into XL-1 Blue $E$. coli by electroporation according to the manufacturer's instructions. An overnight culture of these cells was used to inoculate a $1 \mathrm{~L}$ culture of 2XYT media supplemented with $35 \mu \mathrm{g} \mathrm{mL} \mathrm{m}^{-1}$ kanamycin at an $\mathrm{OD}_{600}$ of 0.05 . Protein expression was induced at an $\mathrm{OD}_{600}$ of 0.8 with $1 \mathrm{mM}$ IPTG. Cells were pelleted by centrifugation and resuspended followed by lysis by sonication. The lysate was cleared by centrifugation at 18,000 rcf for $30 \mathrm{~min}$. His-tagged Flt-1 was purified under denaturing conditions using Ni-NTA resin according to the manufacturer's instructions. Imidazole wash fractions were collected, pooled, and stored at $-20^{\circ} \mathrm{C}$ until required. Collected fractions were thawed on ice, concentrated and FPLC purified using a preparative Hi-Load 16/60 Superdex 75 column (Pharmacia Biotech) equilibrated with denaturing buffer ( $6 \mathrm{M}$ urea, $10 \mathrm{mM}$ Tris- $\mathrm{HCl}, 100 \mathrm{mM} \mathrm{Na}_{2} \mathrm{HPO}_{4}$, $\mathrm{pH}$ 8.0). Flt-1 was refolded overnight at $4^{\circ} \mathrm{C}$ in $2 \mathrm{~L}$ of refolding buffer ( $0.3 \mathrm{M}$ urea, $10 \mathrm{mM}$ Tris- $\mathrm{HCl}, 100 \mathrm{mM} \mathrm{Na}_{2} \mathrm{HPO}_{4}, 5 \mathrm{mM}$ cysteine and $1 \mathrm{mM}$ cystine) in a $3 \mathrm{kDa}$ MWCO dialysis snake-skin tubing (Pierce) at a final concentration of $50-100 \mu \mathrm{g} \mathrm{mL}^{-1}$. After refolding, Flt-1 was subsequently purified in phosphate buffered saline ( $\mathrm{pH} 7.4)$ using an analytical Superdex ${ }^{\mathrm{TM}} 75$ column (Pharmacia Biotech).

Flt-1 Luciferase Fusion mRNA Production. Open reading frames encoding for domain 2 of the Flt-1 receptor were cloned into bacterial vectors containing either the $\mathrm{N}$ - or $\mathrm{C}$-terminal portions of firefly luciferase, residues $2-416$ and $398-550$, respectively (32), separated by a flexible amino acid linker. These plasmid sequences were confirmed by the University of Arizona DNA Sequencing Facility. These constructs were PCR amplified using a $5^{\prime}$ primer encoding a T7 promoter and Kozak sequence and 3' primer containing a stem loop. mRNA was generated using the T7 Ribomax Transcription Kit and purified using a G50 ProbeQuant column. Concentrations of each mRNA were determined by UV absorbance.

VEGF-Flt-1 Sandwich Assay. Translations using Flexi-Rabbit Reticulocyte Lysate were carried out according to the manufacture's procedure using $2 \mathrm{pmol}$ of each mRNA encoding for the Flt-1 fusions, $400 \mu \mathrm{M}$ DT, $70 \mathrm{mM} \mathrm{KCl}, 200 \mu \mathrm{M}$ of each amino acid, $66 \%$ Lysate in $25 \mu \mathrm{L}$. Reactions were incubated at $30^{\circ} \mathrm{C}$ for 90 min after which $75 \mathrm{nM}$ VEGF dimer or an equivalent volume of PBS was added and incubated for $1 \mathrm{~h}$ at RT. Luminescence was monitored on a Turner TD20e luminometer by mixing $10 \mu \mathrm{L}$ of translation with $40 \mu \mathrm{L}$ of Steady-Glo Luciferase Assay System giving a final concentration of $15 \mathrm{nM}$ VEGF dimer. Luminescence was monitored $1 \mathrm{~min}$ after mixing with a $10 \mathrm{~s}$ integration. Reactions were performed in duplicate and averaged.

VEGF Titration. To determine the assay sensitivity, translations using Flexi-Rabbit Reticulocyte Lysate were carried out according to the manufacture's procedure using 2 pmol of each mRNA encoding for the Flt-1 fusions, $400 \mu \mathrm{M}$ DT, $70 \mathrm{mM} \mathrm{KCl}, 200 \mu \mathrm{M}$ of each amino acid, and $66 \%$ Lysate in a $25 \mu \mathrm{L}$ reaction. Translations proceeded at $30^{\circ} \mathrm{C}$ for $90 \mathrm{~min}$, followed by addition of varying concentrations of VEGF dimer or an equivalent volume of PBS. After binding at RT for $1 \mathrm{~h}, 10 \mu \mathrm{L}$ of the reaction was added to $40 \mu \mathrm{L}$ of Steady-Glo Luciferase Assay System, giving final VEGF dimer concentrations of $15,7.5,3.8,1.9,0.9$, or $0.5 \mathrm{nM}$ or no VEGF. Luminescence was monitored 1 min after mixing 
with a $10 \mathrm{~s}$ integration. Reactions were performed in duplicate and averaged.

Flt-1 Titration. Translations using Flexi-Rabbit Reticulocyte Lysate were carried out according to the manufacture's procedure using 2 pmol of each mRNA encoding for the Flt- 1 fusions, $400 \mu \mathrm{M} \mathrm{DTT}, 70 \mathrm{mM} \mathrm{KCl}, 200 \mu \mathrm{M}$ of each amino acid, and $66 \%$ Lysate in a $25 \mu \mathrm{L}$ reaction. Reactions were incubated at $30^{\circ} \mathrm{C}$ for $90 \mathrm{~min}$ after which $22.5 \mu \mathrm{L}$ of the reaction was added to 75 nM VEGF dimer in the presence of varying concentrations of free Flt-1. Binding was allowed to achieve equilibrium at RT for $1 \mathrm{~h}$, followed by addition of $10 \mu \mathrm{L}$ of the reaction to $40 \mu \mathrm{L}$ of SteadyGlo Luciferase Assay System, resulting in final concentrations of $15 \mathrm{nM}$ VEGF dimer and 500, 250, 100, 50, 25, 12.5, 2.3, or $0.4 \mathrm{nM}$ or no Flt-1. Luminescence was monitored $1 \mathrm{~min}$ after mixing with a $10 \mathrm{~s}$ integration. Reactions were performed in duplicate and averaged, followed by normalization to the sample containing $15 \mathrm{nM}$ VEGF and no Flt-1.

Production of mRNA Encoding for the CD4 and 17b SplitLuciferase Fusions. Open reading frames encoding for residues $1-182$ of $C D 4$ and the $V_{H}$ and $V_{L}$ regions of $17 b$ separated by a $(\mathrm{GGGGS})_{3}$ linker were cloned into vectors containing the $\mathrm{N}$ - and C-terminal portions of luciferase respectively. These plasmid sequences were confirmed by the University of Arizona DNA Sequencing Facility. These constructs were PCR amplified using a $5^{\prime}$ primer encoding a T7 promoter and Kozak sequence and 3' primer containing a stem loop. mRNA was generated using the T7 Ribomax Transcription Kit and purified using a G50 ProbeQuant column. Concentrations of each mRNA were determined by UV absorbance.

Effect of DTT and PDI on the gp120 Sandwich Assay. Translations using Flexi-Rabbit Reticulocyte Lysate were carried out according to the manufacture's procedure using 2 pmol of each of the mRNAs encoding the CD4-NFluc and CFluc-17b fusions, $70 \mathrm{mM} \mathrm{KCl}, 20 \mu \mathrm{M}$ of each amino acid, $66 \%$ Lysate, $0.5 \mu \mathrm{L}$ RNasin (resulting in $160 \mu \mathrm{M}$ DT during translation, from the RNasin storage buffer) where indicated, $90 \mu \mathrm{g} \mathrm{mL}^{-1}$ PDI where indicated, and either $100 \mathrm{nM} \mathrm{BaL}$ gp120 or an equivalent volume of PBS in a $25 \mu \mathrm{L}$ reaction. Reactions were incubated at $30^{\circ} \mathrm{C}$ for 90 min after which luminescence was monitored on a Turner TD20e luminometer by mixing $20 \mu \mathrm{L}$ of translation with $80 \mu \mathrm{L}$ of Steady-Glo Luciferase Assay System giving a final concentration of $20 \mathrm{nM} \mathrm{B}_{\mathrm{aL}}$ gp120. Luminescence was monitored $1 \mathrm{~min}$ after mixing with a $10 \mathrm{~s}$ integration. Reactions were performed in duplicate and averaged.

Specificity of the gp120 Sandwich Assay. Translations and luciferase detection were carried out as described above, using $90 \mu \mathrm{gL}^{-1}$ PDI and no RNasin, except that $25 \mathrm{nM}$ of the indicated gp120 was added during translation, giving a final concentration of $5 \mathrm{nM}$ gp120.

Production of mRNA Encoding for the Herceptin and Omnitarg Split-Luciferase Fusions. Open reading frames encoding for the $V_{H}$ and $V_{L}$ regions of Omnitarg and Herceptin separated by a $(\mathrm{GGGGS})_{3}$ linker were cloned into vectors containing the $\mathrm{N}$ - and C-terminal portions of luciferase respectively. These plasmid sequences were confirmed by the University of Arizona DNA Sequencing Facility. These constructs were PCR amplified using a 5' primer encoding a T7 promoter and Kozak sequence and 3' primer containing a stem loop. mRNA was generated using the T7 Ribomax Transcription Kit and purified using a G50 ProbeQuant column. Concentrations of each mRNA were determined by UV absorbance.

Expression, Purification, and Western Blot Analysis of the HER2 ECD. Lec1 cells stably expressing a human growth hormonehistidine tagged-HER2 ECD protein (49) were grown in $95 \%$ $\alpha M E M$ (without nucleotides or L-GIn) and $5 \%$ FBS supplemented with $100 \mathrm{nM}$ methotrexate, $0.5 \mathrm{mg} \mathrm{mL}^{-1} \mathrm{G} 418,584 \mathrm{mg} \mathrm{L}^{-1}$ Ala$\mathrm{Gln}, 100$ units $\mathrm{mL}^{-1}$ penicillin, and $100 \mu \mathrm{g} \mathrm{mL}^{-1}$ streptomycin.
Cell cultures were allowed to grow for three days after which protein was purified from $50 \mathrm{~mL}$ of culture media using Ni-NTA affinity chromatography. Protein was eluted with $10 \mathrm{mM}$ Tris- $\mathrm{HCl}$ at $\mathrm{pH}=7.5$ containing $50 \mathrm{mM} \mathrm{NaCl}$ and $500 \mathrm{mM}$ imidazole. This solution was used directly for the experiments described below.

Western blot analysis was performed using a rabbit anti-histag polyclonal primary antibody (QED Biosciences, 18814) and an IR dye conjugated antirabbit secondary goat antibody (Licor Biosciences, IgG IRDye 800CW, 926-32211). A Licor Biosciences Odyssey scanner was used for imaging. HER2 ECD concentration was estimated from SDS-PAGE analysis.

HER2 Sandwich Assay using Purified HER2 ECD. Translations using Flexi-Rabbit Reticulocyte Lysate were carried out according to the manufacture's procedure using $2 \mathrm{pmol}$ of each of the mRNAs encoding the Omnitarg-NFluc and CFluc-Herceptin fusions, $70 \mathrm{mM} \mathrm{KCl}, 20 \mu \mathrm{M}$ of each amino acid, $66 \%$ Lysate, and $90 \mu \mathrm{g} \mathrm{mL}^{-1} \mathrm{PDI}$ in a $25 \mu \mathrm{L}$ reaction. Reactions were incubated at $30^{\circ} \mathrm{C}$ for 90 min after which purified HER2 ECD or an equivalent volume of storage buffer $(10 \mathrm{mM}$ Tris- $\mathrm{HCl}$ at $\mathrm{pH}=7.5$, $50 \mathrm{mM} \mathrm{NaCl}$, and $500 \mathrm{mM}$ imidazole) was added to the translation. These solutions were allowed to equilibrate at RT for 30 min. Luminescence was monitored on a Turner TD20e luminometer by mixing $20 \mu \mathrm{L}$ of translation with $80 \mu \mathrm{L}$ of Steady-Glo Luciferase Assay System. Readings were taken $1 \mathrm{~min}$ after mixing with a $10 \mathrm{~s}$ integration. Reactions were performed in duplicate, background subtracted (using samples containing no HER2 ECD), and averaged. HER2 ECD concentrations after rapid dilution are shown.

HER2 Sandwich Assay Using Human Breast Cancer Cells. SK-BR3, BT-474, and MCF7 cells were grown in 90\% RPMI 1640 and $10 \%$ FBS supplemented with 100 units $\mathrm{mL}^{-1}$ penicillin, $100 \mu \mathrm{g}$ $\mathrm{mL}^{-1}$ streptomycin, and $0.1 \%$ fungizone. Cells were detached using PBS containing $25 \mathrm{mM}$ EDTA, washed, and resuspended in PBS; after which they were counted by Trypan Blue exclusion. Cells were diluted to $1.4 \times 10^{4}$ cells $\mu \mathrm{L}^{-1}$ prior to use in the assay.

Translations using Flexi-Rabbit Reticulocyte Lysate were carried out according to the manufacture's procedure using $2 \mathrm{pmol}$ of each of the mRNAs encoding the Omnitarg-NFluc and CFlucHerceptin fusions, $70 \mathrm{mM} \mathrm{KCl}, 20 \mu \mathrm{M}$ of each amino acid, and $66 \%$ Lysate per $25 \mu \mathrm{L}$ reaction. Reactions were incubated at $30^{\circ} \mathrm{C}$ for $90 \mathrm{~min}$ after which $5 \mu \mathrm{L}$ of cells or an equivalent volume of PBS was added. These solutions were allowed to equilibrate at RT for 40 min with gentle shaking. Luminescence was monitored on a Turner $20 / 20^{\mathrm{n}}$ or TD20e luminometer by mixing $20 \mu \mathrm{L}$ of translation with $80 \mu \mathrm{L}$ of Steady-Glo Luciferase Assay System. Luminescence was monitored 1 min after mixing with a $10 \mathrm{~s}$ integration. The luminescence readings are from assays that were performed in duplicate on cells grown in separate flasks, background subtracted (using samples containing no cells), and averaged. The number of cells in the luminescence assay is reported.

Acknowledgment: J.L.F. and J.R.P. were supported by a National Institutes of Health Institutional Training Grant (5T32GM008804-05). We thank the NIH for support (R01Al068414). We thank P. Longo, K. Block, and B. Fritz for helpful discussions; S. Rana for initial Flt-1 constructs, B. Olenyuk for providing the MCF7 cell line, D. Leahy for providing the HER2 ECD expressing Lec1 cell line, and the NIH AIDS repository for HIV-1 reagents.

Supporting Information Available: This material is available free of charge via the Internet at http://pubs.acs.org.

\section{REFERENCES}

1. Santarius, T., Shipley, J., Brewer, D., Stratton, M. R., and Cooper, C. S. (2010) A census of amplified and overexpressed human cancer genes, Nat. Rev. Cancer 10, 59-64. 
2. Musgrove, E. A., and Sutherland, R. L. (2009) Biological determinants of endocrine resistance in breast cancer, Nat. Rev. Cancer 9 , 631-643.

3. Kwong, P. D., Wyatt, R., Robinson, J., Sweet, R. W., Sodroski, J., and Hendrickson, W. A. (1998) Structure of an HIV gp120 envelope glycoprotein in complex with the CD4 receptor and a neutralizing human antibody, Nature 393, 648-659.

4. Fischer, C., Mazzone, M., Jonckx, B., and Carmeliet, P. (2008) FLT1 and its ligands VEGFB and PIGF: drug targets for anti-angiogenic therapy? Nat. Rev. Cancer 8, 942-956.

5. Chen, I., and Ting, A. Y. (2005) Site-specific labeling of proteins with small molecules in live cells, Curr. Opin. Biotechnol. 16, 35-40.

6. Parks, D. R., and Herzenberg, L. A. (1984) Fluorescence-activated cell sorting-Theory, experimental optimization, and applications in lymphoid-cell biology, Methods Enzymol. 108, 197-241.

7. Engvall, E., and Perlmann, P. (1971) Enzyme-linked immunosorbent assay (ELISA) quantitative assay of immunoglobulin-G, Immunochemistry $8,871-874$.

8. Van Weeme, B. K., and Schuurs, A. H. W. (1971) Immunoassay using antigen-enzyme conjugates, FEBS Lett. 15, 232-236.

9. Selvin, P. R. (2002) Principles and biophysical applications of lanthanide-based probes, Annu. Rev. Biophys. Biomol. Struct. 31, 275-302.

10. Inglese, J., Johnson, R. L., Simeonov, A., Xia, M. H., Zheng, W., Austin, C. P., and Auld, D. S. (2007) High-throughput screening assays for the identification of chemical probes, Nat. Chem. Biol. 3, 466479.

11. Michnick, S. W., Ear, P. H., Manderson, E. N., Remy, I., and Stefan, E. (2007) Universal strategies in research and drug discovery based on protein-fragment complementation assays, Nat. Rev. Drug Discovery 6, 569-582.

12. Muller, J., and Johnsson, N. (2008) Split-ubiquitin and the splitprotein sensors: Chessman for the endgame, ChemBioChem 9, 2029-2038.

13. Johnsson, N., and Varshavsky, A. (1994) Split ubiquitin as a sensor of protein interactions in vivo, Proc. Natl. Acad. Sci. U.S.A. 91, 10340-10344.

14. Pelletier, J. N., Campbell-Valois, F. X., and Michnick, S. W. (1998) Oligomerization domain-directed reassembly of active dihydrofolate reductase from rationally designed fragments, Proc. Natl. Acad. Sci. U.S.A. 95, 12141-12146.

15. Galarneau, A., Primeau, M., Trudeau, L. E., and Michnick, S. W. (2002) $\beta$-Lactamase protein fragment complementation assays as in vivo and in vitro sensors of protein-protein interactions, Nat. Biotechnol. 20, 619-622.

16. Ghosh, I., Hamilton, A. D., and Regan, L. (2000) Antiparallel leucine zipper-directed protein reassembly: Application to the green fluorescent protein, J. Am. Chem. Soc. 122, 5658-5659.

17. Hu, C. D., and Kerppola, T. K. (2003) Simultaneous visualization of multiple protein interactions in living cells using multicolor fluores cence complementation analysis, Nat. Biotechnol. 21, 539-545.

18. MacDonald, M. L., Lamerdin, J., Owens, S., Keon, B. H., Bilter, G. K., Shang, Z., Huang, Z., Yu, H., Dias, J., Minami, T., Michnick, S. W., and Westwick, J. K. (2006) Identifying off-target effects and hidden phenotypes of drugs in human cells, Nat. Chem. Biol. 2, 329-337.

19. Paulmurugan, R., and Gambhir, S. S. (2003) Monitoring proteinprotein interactions using split synthetic renilla luciferase proteinfragment-assisted complementation, Anal. Chem. 75, 1584-1589.

20. Remy, I., and Michnick, S. W. (2006) A highly sensitive proteinprotein interaction assay based on Gaussia luciferase, Nat. Methods 3, 977-979.

21. Paulmurugan, R., Umezawa, Y., and Gambhir, S. S. (2002) Noninvasive imaging of protein-protein interactions in living subjects by using reporter protein complementation and reconstitution strategies, Proc. Natl. Acad. Sci. U.S.A. 99, 15608-15613.
22. Tafelmeyer, P., Johnsson, N., and Johnsson, K. (2004) Transforming a $(\beta / \alpha)(8)$-barrel enzyme into a split-protein sensor through directed evolution, Chem. Biol. 11, 681-689.

23. Wehr, M. C., Laage, R., Bolz, U., Fischer, T. M., Grunewald, S., Scheek, S., Bach, A., Nave, K.-A., and Rossner, M. J. (2006) Monitoring regulated protein-protein interactions using split TEV, Nat. Methods 3, 985-993.

24. Muller, M. M., Kries, H., Csuhai, E., Kast, P., and Hilvert, D. (2010) Design, selection, and characterization of a split chorismate mutase, Protein Sci. 19, 1000-1010.

25. Tarassov, K., Messier, V., Landry, C. R., Radinovic, S., Molina, M. M. S., Shames, I., Malitskaya, Y., Vogel, J., Bussey, H., and Michnick, S. W. (2008) An in vivo map of the yeast protein interactome, Science 320, 1465-1470.

26. Varshavsky, A. (2007) Targeting the absence: Homozygous DNA deletions as immutable signposts for cancer therapy, Proc. Natl. Acad. Sci. U.S.A. 104, 14935-14940.

27. Furman, J. L., Badran, A. H., Shen, S. Y., Stains, C. I., Hannallah, J., Segal, D. J., and Ghosh, I. (2009) Systematic evaluation of splitfluorescent proteins for the direct detection of native and methylated DNA, Bioorg. Med. Chem. Lett. 19, 3748-3751.

28. Stains, C. I., Furman, J. L., Segal, D. J., and Ghosh, I. (2006) Sitespecific detection of DNA methylation utilizing mCpG-SEER, J. Am. Chem. Soc. 128, 9761-9765.

29. Stains, C. I., Porter, J. R., Ooi, A. T., Segal, D. J., and Ghosh, I. (2005) DNA sequence-enabled reassembly of the green fluorescent protein, J. Am. Chem. Soc. 127, 10782-10783.

30. Nomura, W., and Barbas, C. F. (2007) In vivo site-specific DNA methylation with a designed sequence-enabled DNA methylase, J. Am. Chem. Soc. 129, 8676-8677.

31. Porter, J. R., Stains, C. I., Jester, B. W., and Ghosh, I. (2008) A general and rapid cell-free approach for the interrogation of proteinprotein, protein-DNA, and protein-RNA interactions and their antag onists utilizing split-protein reporters, J. Am. Chem. Soc. 130, 6488-6497.

32. Luker, K. E., Smith, M. C. P., Luker, G. D., Gammon, S. T., PiwnicaWorms, H., and Piwnica-Worms, D. P. (2004) Kinetics of regulated protein-protein interactions revealed with firefly luciferase complementation imaging in cells and living animals, Proc. Natl. Acad. Sci. U.S.A. 101, 12288-12293.

33. Ostermeier, M., Nixon, A. E., Shim, J. H., and Benkovic, S. J. (1999) Combinatorial protein engineering by incremental truncation, Proc. Natl. Acad. Sci. U.S.A. 96, 3562-3567.

34. Goto, Y., Ohta, A., Sako, Y., Yamagishi, Y., Murakami, H., and Suga, H. (2008) Reprogramming the translation Initiation for the synthesis of physiologically stable cyclic peptides, ACS Chem. Biol. 3, $120-129$.

35. Shimizu, Y., Inoue, A., Tomari, Y., Suzuki, T., Yokogawa, T., Nishikawa, K., and Ueda, T. (2001) Cell-free translation reconstituted with purified components, Nat. Biotechnol. 19, 751-755.

36. Wiesmann, C., Fuh, G., Christinger, H. W., Eigenbrot, C., Wells, J. A., and deVos, A. M. (1997) Crystal structure at 1.7 angstrom resolution of VEGF in complex with domain 2 of the Flt-1 receptor, Cell 91, 695-704.

37. Bird, R. E., Hardman, K. D., Jacobson, J. W., Johnson, S., Kaufman, B. M., Lee, S. M., Lee, T., Pope, S. H., Riordan, G. S., and Whitlow, M. (1988) Single-chain antigen-binding proteins, Science 242, 423426.

38. Holliger, P., and Hudson, P. J. (2005) Engineered antibody fragments and the rise of single domains, Nat. Biotechnol. 23, 11261136.

39. Huston, J. S., Levinson, D., Mudgetthunter, M., Tai, M. S., Novotny, J., Margolies, M. N., Ridge, R. J., Bruccoleri, R. E., Haber, E., Crea, R., and Oppermann, H. (1988) Protein engineering of antibodybinding sites-Recovery of specific activity in an anti-digoxin singlechain Fv analog produced in Escherichia coli, Proc. Natl. Acad. Sci. U.S.A. 85, 5879-5883. 
40. Mössner, E., Koch, H., and Plückthun, A. (2001) Fast selection of antibodies without antigen purification: adaptation of the protein fragment complementation assay to select antigen-antibody pairs, J. Mol. Biol. 308, 115-122.

41. Biocca, S., Ruberti, F., Tafani, M., Pierandrel-Amaldi, P., and Cattaneo, A. (1995) Redox state of single chain Fv fragments targeted to the endoplasmic reticulum, cytosol and mitochondria, Nat. Biotechnol. 13, 1110-1115.

42. Koch, H., Gräfe, N., Schiess, R., and Plückthun, A. (2006) Direct selection of antibodies from complex libraries with the protein fragment complementation assay, J. Mol. Biol. 357, 427-441.

43. Ryabova, L. A., Desplancq, D., Spirin, A. S., and Plückthun, A. (1997) Functional antibody production using cell-free translation: Effects of protein disulfide isomerase and chaperones, Nat. Biotechnol. 15, 79-84.

44. Lagenaur, L. A., Villarroel, V. A., Bundoc, V., Dey, B., and Berger, E. A. (2010) sCD4-17b bifunctional protein: Extremely broad and potent neutralization of HIV-1 Env pseudotyped viruses from genetically diverse primary isolates, Retrovirology 7, .

45. Ryu, S. E., Kwong, P. D., Truneh, A., Porter, T. G., Arthos, J., Rosenberg, M., Dai, X. P., Xuong, N. H., Axel, R., Sweet, R. W., and Hendrickson, W. A. (1990) Crystal-structure of an HIV-binding recombinant fragment of human CD4, Nature 348, 419-426.

46. Olshevsky, U., Helseth, E., Furman, C., Li, J., Haseltine, W., and Sodroski, J. (1990) Identification of individual human immunodeficiency virus type 1 gp120 amino acids important for CD4 receptor binding, J. Virol. 64, 5701-5707.

47. Thali, M., Moore, J. P., Furman, C., Charles, M., Ho, D. D., Robinson, J., and Sodroski, J. (1993) Characterization of conserved human immunodeficiency virus type 1 gp120 neutralization epitopes exposed upon gp120-CD4 binding, J. Virol. 67, 3978-3988.

48. Binley, J. A., Wrin, T., Korber, B., Zwick, M. B., Wang, M., Chappey, C., Stiegler, G., Kunert, R., Zolla-Pazner, S., Katinger, H., Petropoulos, C. J., and Burton, D. R. (2004) Comprehensive cross-clade neutralization analysis of a panel of anti-human immunodeficiency virus type 1 monoclonal antibodies, J. Virol. 78, 13232-13252.

49. Cho, H. S., Mason, K., Ramyar, K. X., Stanley, A. M., Gabelli, S. B., Denney, D. W., and Leahy, D. J. (2003) Structure of the extracellular region of HER2 alone and in complex with the Herceptin Fab, Nature 421, 756-760.

50. Franklin, M. C., Carey, K. D., Vajdos, F. F., Leahy, D. J., de Vos, A. M., and Sliwkowski, M. X. (2004) Insights into ErbB signaling from the structure of the ErbB2-pertuzumab complex, Cancer Cell 5, 317328.

51. Kubetzko, S., Balic, E., Waibel, R., Zangemeister-Wittke, U., and Plückthun, A. (2006) PEGylation and multimerization of the antip185(HER-2) single chain Fv fragment 4D5-Effects on tumor targeting, J. Biol. Chem. 281, 35186-35201.

52. Adams, C. W., Allison, D. E., Flagella, K., Presta, L., Clarke, J., Dybdal, N., McKeever, K., and Sliwkowski, M. X. (2006) Humanization of a recombinant monoclonal antibody to produce a therapeutic HER dimerization inhibitor, pertuzumab, Cancer Immunol. Immunother. 55, 717-727.

53. Prang, N., Preithner, S., Brischwein, K., Goster, P., Woppel, A., Muller, J., Steiger, C., Peters, M., Baeuerle, P. A., and da Silva, A. J. (2005) Cellular and complement-dependent cytotoxicity of Ep-CAMspecific monoclonal antibody MT201 against breast cancer cell lines, Br. J. Cancer 92, 342-349.

54. Kraft, A., Weindel, K., Ochs, A., Marth, C., Zmija, J., Schumacher, P., Unger, C., Marme, D., and Gastl, G. (1999) Vascular endothelial growth factor in the sera and effusions of patients with malignant and nonmalignant disease, Cancer 85, 178-187.

55. Winter, G., Griffiths, A. D., Hawkins, R. E., and Hoogenboom, H. R. (1994) Making antibodies by phage display technology, Annu. Rev. Immunol. 12, 433-455.

56. Pera, M. F., and Tam, P. P. L. (2010) Extrinsic regulation of pluripotent stem cells, Nature 465, 713-720.
57. Rice, B. W., Cable, M. D., and Nelson, M. B. (2001) In vivo imaging of light-emitting probes, J. Biomed. Opt. 6, 432-440.

58. Hida, N., Awais, M., Takeuchi, M., Ueno, N., Tashiro, M., Takagi, C., Singh, T., Hayashi, M., Ohmiya, Y., and Ozawa, T. (2009) Highsensitivity real-time imaging of dual protein-protein interactions in living subjects using multicolor luciferases, PLoS One 4, e5868.

59. Li, X. Y., Nakajima, Y., Niwa, K., Viviani, V. R., and Ohmiya, Y. (2010) Enhanced red-emitting railroad worm luciferase for bioassays and bioimaging, Protein Sci. 19, 26-33.

60. Carter, P., Presta, L., Gorman, C. M., Ridgway, J. B. B., Henner, D., Wong, W. L. T., Rowland, A. M., Kotts, C., Carver, M. E., and Shepard, H. M. (1992) Humanization of an anti-P185Her2 antibody for human cancer therapy, Proc. Natl. Acad. Sci. U.S.A. 89, 42854289. 


\section{A General Approach for Receptor and Antibody-Targeted Detection of Native Proteins Utilizing Split-Luciferase Reassembly}

Cliff I. Stains ${ }^{1 \dagger}$, Jennifer L. Furman ${ }^{1 \dagger}$, Jason R. Porter ${ }^{1}$, Srivats Rajagopal ${ }^{1}$, Yuxing Li $^{2}$, Richard T. Wyatt ${ }^{2,3}$, and Indraneel Ghosh ${ }^{1, *}$

${ }^{1}$ Department of Chemistry and Biochemistry, University of Arizona

${ }^{2}$ Vaccine Research Center, National Institutes of Health

${ }^{3}$ Present Address, Department of Immunology, The Scripps Research Institute

${ }^{\dagger}$ These authors contributed equally to this work

*Corresponding author: ghosh@email.arizona.edu

\section{Supporting Information}




\section{Supporting Methods}

Association between VEGF and Flt-1. Following successful expression and refolding of VEGF and Flt-1, we established correct folding by monitoring association. VEGF dimer and Flt-1 were mixed in a 1:2 molar ratio and equilibrated at $4{ }^{\circ} \mathrm{C}$ for 2 hours. As controls for this experiment, VEGF and Flt-1 were separately injected into a sizeexclusion column at the same concentration, which resulted in specific retention volumes on the column (Figure S2). Injection of the mixture of VEGF and Flt-1 into the column resulted in a peak corresponding to a retention volume that is distinct from either VEGF or Flt-1 alone. To ascertain the molecular weight of the complex, protein standards were run separately to establish a calibration curve (Figure S3). As expected, the VEGF-Flt-1 complex peak corresponds to a 1:2 complex where two copies of Flt-1 bind a single VEGF homodimer.

Effect of protease inhibitors and detergent on VEGF detection. We analyzed the effect of (1) Protease Inhibitor Cocktail (Sigma, product P8849) containing 4-(2aminoethyl)benzenesulfonyl fluoride (AEBSF), bestatin, pepstatin A, E-64, and phosphoramidon as well as (2) M-PER® Mammalian Protein Extraction Reagent (Pierce, product 78503), which utilizes a proprietary detergent in $25 \mathrm{mM}$ Bicine buffer at pH 7.6 for mammalian cell lysis. To perform the experiment, translations of CLuciferaseFlt-1 and Flt-1-NLuciferase were carried out, followed by addition of $1.25 \mu \mathrm{L}$ of $1.5 \mu \mathrm{M}$ VEGF dimer or PBS and 1.25 $\mu \mathrm{L}$ of 1x Protease Inhibitor Cocktail, M-PER or water. The reactions were incubated at room temperature for one hour, followed by luminescence readings consisting of addition of $10 \mu \mathrm{L}$ of the reaction to $40 \mu \mathrm{L}$ of Steady-Glo Luciferase Assay System. Results are presented as the luminescence of the sample in the presence of VEGF relative to the sample containing PBS (Figure S4).

Initial gp120 Sandwich Assay. Translations using Flexi-Rabbit Reticulocyte Lysate were carried out according to the manufactures procedure using 2 pmols of each of the mRNAs encoding the CD4-NFluc and CFluc-17b fusions, $0.5 \mu \mathrm{L}$ RNasin, $70 \mathrm{mM} \mathrm{KCl}$, $20 \mu \mathrm{M}$ of each amino acid, $66 \%$ Lysate, and either $100 \mathrm{nM} \mathrm{BaL}$ gp120 or an equivalent 
volume of PBS in a $25 \mu \mathrm{L}$ reaction. Reactions were incubated at $30{ }^{\circ} \mathrm{C}$ for 90 min after which luminescence was monitored on a Turner TD20e luminometer by mixing $20 \mu \mathrm{L}$ of translation with $80 \mu \mathrm{L}$ of Steady-Glo Luciferase Assay System giving a final concentration of $20 \mathrm{nM} \mathrm{B}_{\mathrm{aL}}$ gp120. Reactions were performed in duplicate and averaged (Figure S5).

gp120 Titration. Translations using Flexi-Rabbit Reticulocyte Lysate were carried out according to the manufactures procedure using 2 pmols of each of the mRNAs encoding the CD4-NFluc and CFluc-17b fusions, $90 \mu \mathrm{gL}^{-1}$ PDI, $70 \mathrm{mM} \mathrm{KCl}, 20 \mu \mathrm{M}$ of each amino acid, $66 \%$ Lysate, and decreasing concentrations of $\mathrm{B}_{\mathrm{aL}}$ gp120 or an equivalent volume of PBS in a $25 \mu \mathrm{L}$ reaction. Reactions were incubated at $30{ }^{\circ} \mathrm{C}$ for 90 min after which luminescence was monitored on a Turner TD20e luminometer by mixing $20 \mu \mathrm{L}$ of translation with $80 \mu \mathrm{L}$ of Steady-Glo Luciferase Assay System. Luminescence was monitored 1 min after mixing with a $10 \mathrm{sec}$ integration. Reactions were performed in duplicate, background subtracted (using samples containing no gp120), and averaged. Concentrations of gp120 after rapid dilution are shown (Figure S6)

HER2 Sandwich Assay after Storage at $-80^{\circ} \mathbf{C}$. Two $25 \mu \mathrm{L}$ translations were carried out as described above. Reactions were incubated at $30{ }^{\circ} \mathrm{C}$ for $90 \mathrm{~min}$, flash frozen, and stored at $-80{ }^{\circ} \mathrm{C}$ for 7 days. Solutions were thawed and purified HER2 ECD or an equivalent volume of storage buffer $(10 \mathrm{mM}$ Tris- $\mathrm{HCl}$ at $\mathrm{pH}=7.5,50 \mathrm{mM} \mathrm{NaCl}$, and 500 $\mathrm{mM}$ imidazole) was added to the vials. These solutions were allowed to equilibrate at room temperature for $30 \mathrm{~min}$. Luminescence was monitored on a Turner 20/20 ${ }^{\mathrm{n}}$ luminometer by mixing $20 \mu \mathrm{L}$ of translation with $80 \mu \mathrm{L}$ of Steady-Glo Luciferase Assay System. Luminescence was monitored $1 \mathrm{~min}$ after mixing with a $10 \mathrm{sec}$ integration. Readings are compared to previous translations described above; HER2 ECD concentrations after rapid dilution are shown (Figure S7). 


\section{Figures and Legends}

A

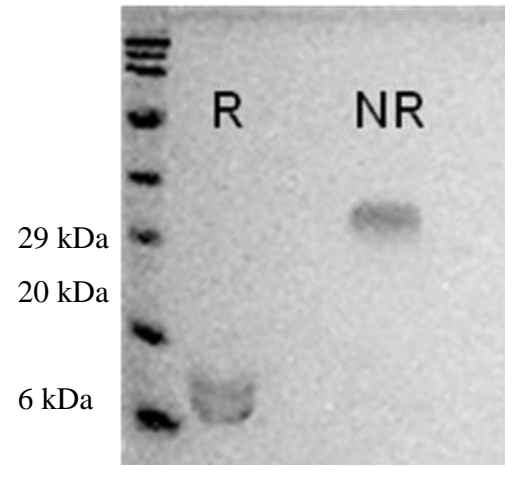

B

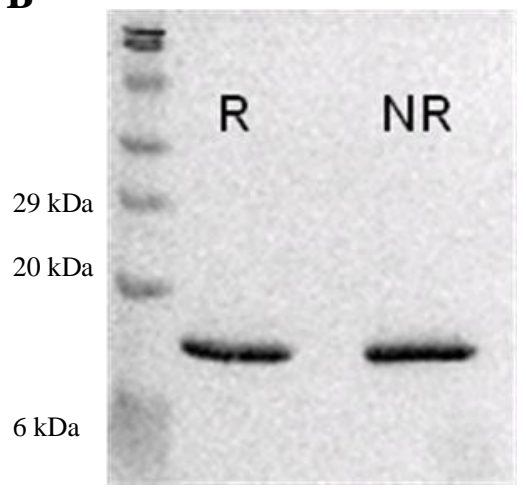

Figure S1. SDS-PAGE gels depicting refolding of proteins seen under reducing $(\mathrm{R})$ and non-reducing (NR) conditions. (A) VEGF protein showing its native dimeric state seen under non-reducing conditions and (B) the monomeric receptor Flt-1 showing the same molecular weight under reducing and non-reducing conditions. 


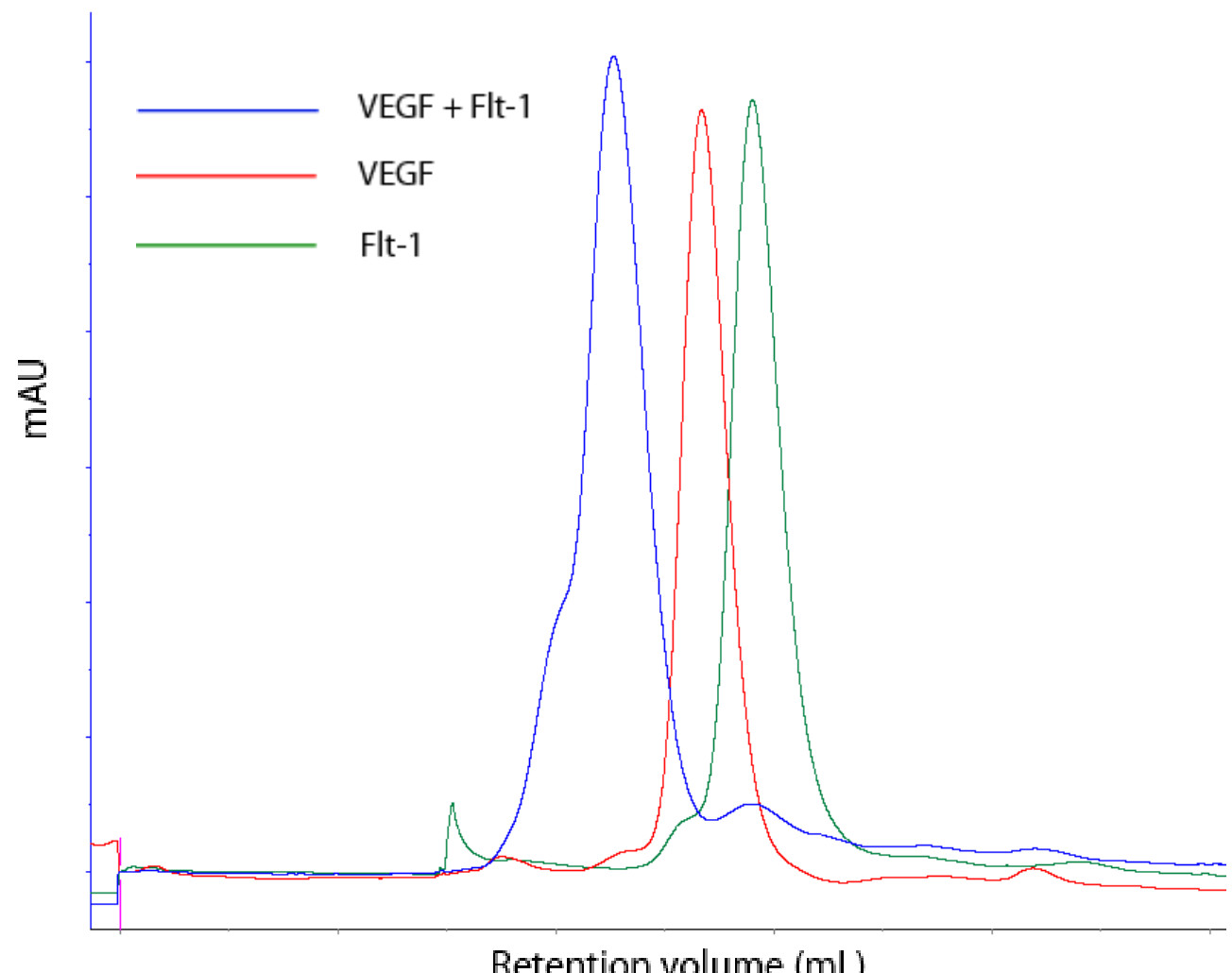

Figure S2. FPLC binding experiment between VEGF and its receptor, Flt-1. The VEGF protein (shown in red) and the Flt-1 protein (green) were run separately on the column. The mixture containing VEGF and Flt-1 (blue) was injected after a $2 \mathrm{~h}$ incubation time on the column. The distinct difference in retention volume of the mixture peak suggests that VEGF and Flt-1 associate in solution. 


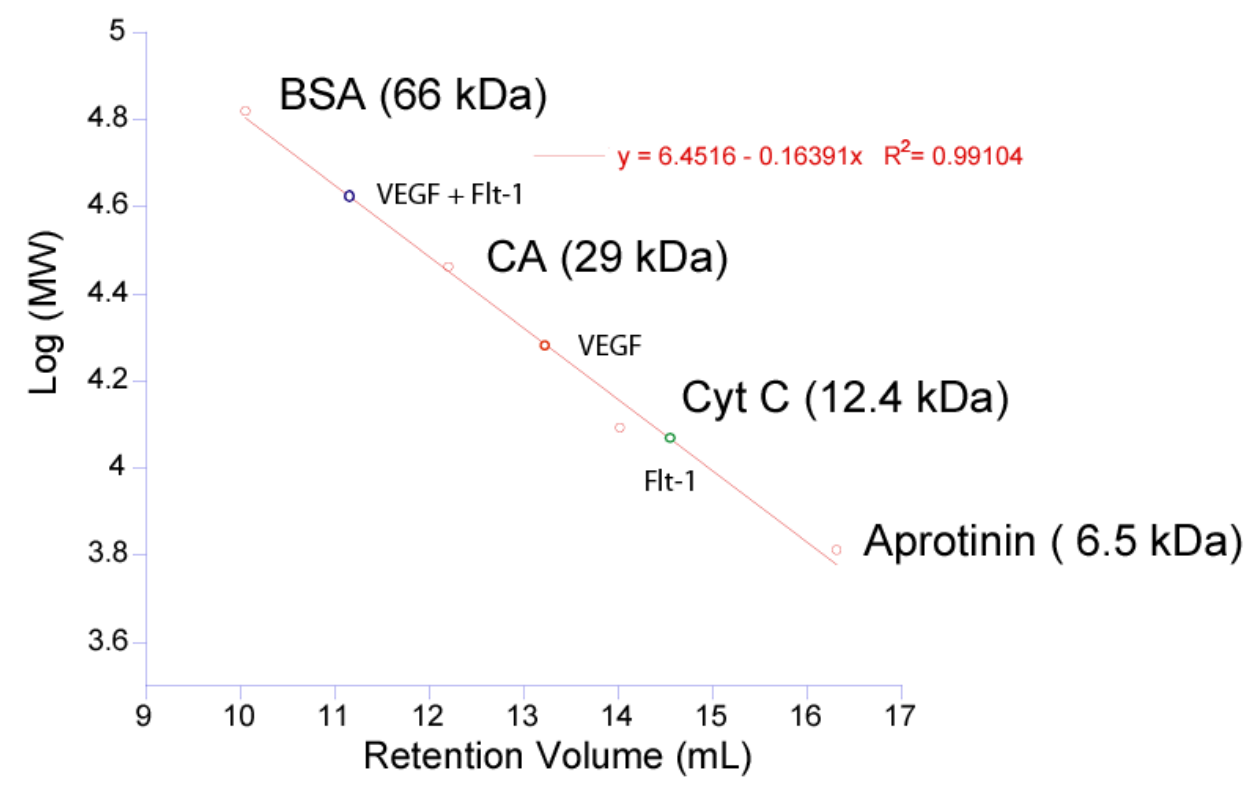

Figure S3. Protein standards run on the size-exclusion column overlaid with the experimental results of the VEGF-Flt-1 binding experiment. On deconvolution of the retention volumes to molecular weights, the results obtained were as follows: 1. Flt-1 (Theoretical MW = 13.6 kDa; Experimental MW = 11.152 kDa). 2. VEGF homodimer (Theretical $\mathrm{MW}=27 \mathrm{kDa}$; Experimental $\mathrm{MW}=18.33 \mathrm{kDa}$ ). 3. Complex between VEGF and Flt-1 (Experimental MW $=39.4 \mathrm{kDa}$ ). These results suggest a 1:2 binding between VEGF and Flt-1 where two copies of Flt-1 bind a single VEGF homodimer. 


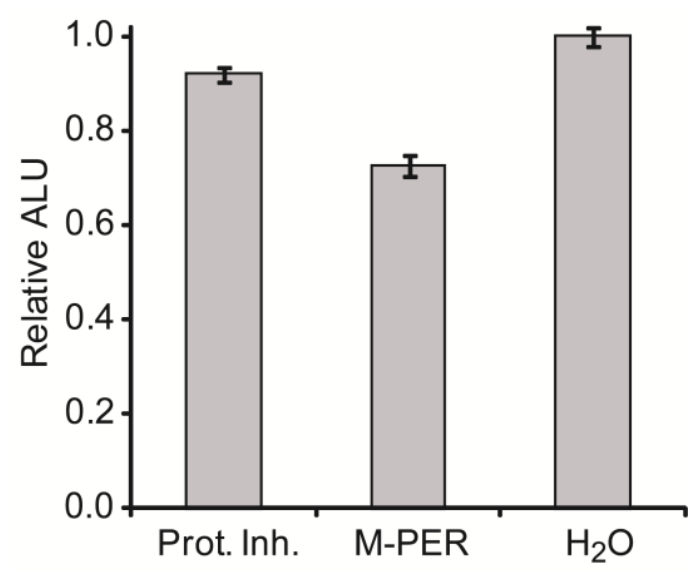

Figure S4. Effect of protease inhibitors and detergents on luciferase reassembly. Translations of CLuciferase-Flt-1 and Flt-1-NLuciferase were incubated with $15 \mathrm{nM}$ VEGF or an equivalent volume of PBS in the presence of a protease inhibitor cocktail (Prot. Inh.), mammalian protein extraction reagent (M-PER), or water $\left(\mathrm{H}_{2} \mathrm{O}\right)$. Luminescence readings are presented as the signal in the presence of VEGF relative to PBS. 


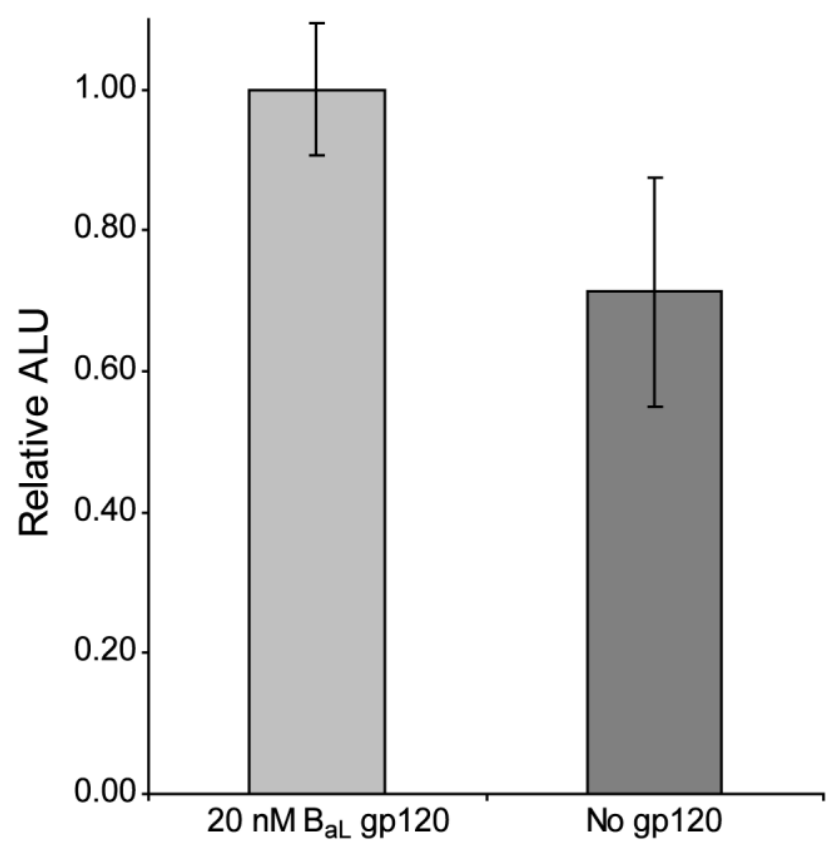

Figure S5. Luminescence in the presence and absence of $B_{a L}$ gp120 for the initial gp120 sandwich assay. 


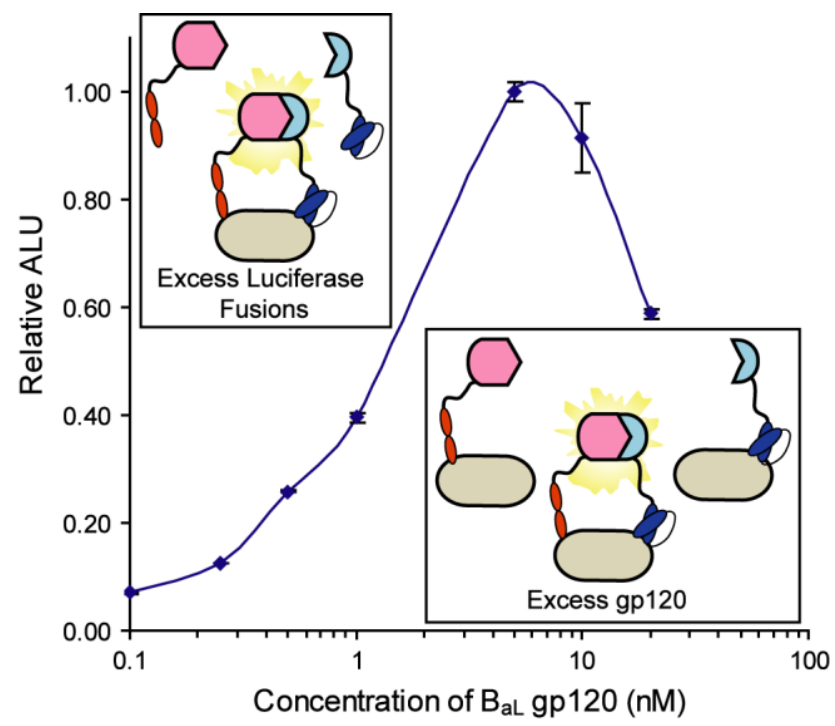

Figure S6. Luminescence from reassembled luciferase was monitored as a function of the concentration of gp120. Initially luciferase fusions are in excess however, as the concentration of gp120 increases, a maximum is reached were the concentration of luciferase fusions capable of forming a functional complex is equivalent to that of gp120. As the gp120 concentration is increased further, luminescence decreases due to localization of the luciferase fusions to different gp120s. 


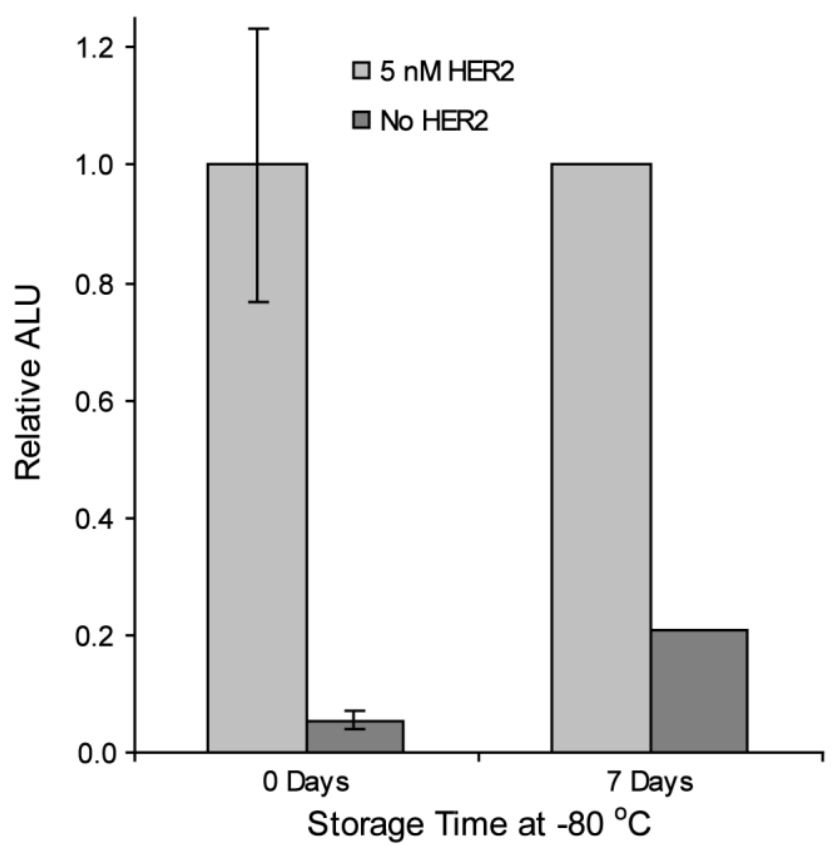

Figure S7. Cell-free translations of the HER2 sandwich assay were flash frozen and stored at $-80{ }^{\circ} \mathrm{C}$ for 7 days; after which purified HER2 ECD was added and luminescence was monitored. Comparable HER2-dependent luciferase activity is still observed after storage for 7 days at $-80{ }^{\circ} \mathrm{C}$. 


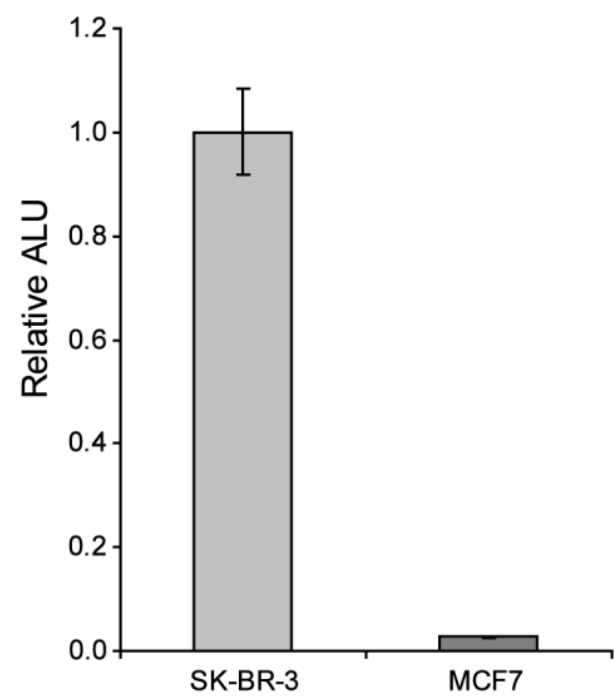

Figure S8. Luminescence as observed from the HER2 sandwich assay performed on 2,600 cells from the indicated human breast cancer cell lines. 